\title{
Tunable white light emission by variation of composition and defects of electrospun $\mathrm{Al}_{2} \mathrm{O}_{3}-\mathrm{SiO}_{2}$ nanofibers
}

\author{
Jinyuan Zhou ${ }^{* 1}$, Gengzhi Sun ${ }^{2}$, Hao Zhao ${ }^{1}$, Xiaojun Pan ${ }^{1}$, Zhenxing Zhang ${ }^{1}$, Yujun Fu ${ }^{1}$, \\ Yanzhe $\mathrm{Mao}^{1}$ and Erqing $\mathrm{Xie}^{1}$
}

Open Access

\author{
Full Research Paper \\ Address: \\ ${ }^{1}$ School of Physical Science and Technology, Lanzhou University, \\ Lanzhou, Gansu 730000, People's Republic of China, and ${ }^{2}$ School of \\ Mechanical and Aerospace Engineering, Nanyang Technological \\ University, 50 Nanyang Avenue, 639798, Singapore \\ Email: \\ Jinyuan Zhou* - zhoujy@lzu.edu.cn \\ * Corresponding author \\ Keywords: \\ $\mathrm{Al}_{2} \mathrm{O}_{3}-\mathrm{SiO}_{2}$; defects; electrospinning; nanofibers; photoluminescence; \\ white light emission
}

Beilstein J. Nanotechnol. 2015, 6, 313-320.

doi:10.3762/bjnano.6.29

Received: 24 September 2014

Accepted: 22 December 2014

Published: 28 January 2015

Associate Editor: A. J. Meixner

(c) 2015 Zhou et al; licensee Beilstein-Institut. License and terms: see end of document.

\begin{abstract}
Composite nanofibers consisting of $\mathrm{Al}_{2} \mathrm{O}_{3}-\mathrm{SiO}_{2}$ were prepared by electrospinning in combination with post-calcination in air. X-ray diffraction, scanning electron microscopy, and transmission electron microscopy were used to investigate the crystalline phase and microstructure of the composite nanofibers. Photoluminescence experiments indicated that the resulting white light emission can be tuned by the relative intensity of the individual spectral components, which are related to the individual defects such as: violet-blue emission from $\mathrm{O}$ defects, green emission from $\equiv \mathrm{Si}(\mathrm{Al})-\mathrm{O}-\mathrm{C} \cdot=\mathrm{O}$, and red emission from intersystem radiative crossing. White light emission was realized at a $\mathrm{Al} /(\mathrm{Al}-\mathrm{Si})$ ratio of 40 and $60 \mathrm{~mol} \%$. This research may offer a deeper understanding of the preparation of efficient and environmentally friendly, white luminescence materials.
\end{abstract}

\section{Introduction}

During the last decade, nanoscale $\mathrm{SiO}_{2}$ has been intensely investigated as a new silicon-based light-emitting material. Its wide photoluminescence (PL) band ranges from the UV to red wavelengths, allowing for potential application in white light emission devices. It has been demonstrated that the luminescence emission and emission intensity of $\mathrm{SiO}_{2}$ nanostructures are strongly dependent upon the intrinsic structural defects and extrinsic environmental influences introduced during the preparation processes, which can be effectively tuned and controlled by doping [1-4]. Thus far, in order to achieve enhanced and stable light emission, various materials have been incorporated into a $\mathrm{SiO}_{2}$ matrix, such as $\mathrm{Si}$ nanocrystals, carbon nanocomposites, $\mathrm{ZnO}, \mathrm{Al}_{2} \mathrm{O}_{3}, \mathrm{SnO}_{2}$, and various rare-earth elements [5-9].

Among those materials, $\mathrm{Al}_{2} \mathrm{O}_{3}$ is one of the most important materials in the history of ceramics, and has been extensively applied in catalysts, coatings, microelectronics and various 
devices, due to its excellent physical and chemical stability, high dielectric constant, wide band gap energy, and relatively high refractive index [10]. Similar to $\mathrm{SiO}_{2}, \mathrm{Al}_{2} \mathrm{O}_{3}$ is inexpensive and environmentally friendly, as well as highly compatible with the current integrated circuit processes. It has been demonstrated that the PL properties of $\mathrm{SiO}_{2} / \mathrm{Al}_{2} \mathrm{O}_{3}$ composites are more suitable than those of pure $\mathrm{SiO}_{2}$ or $\mathrm{Al}_{2} \mathrm{O}_{3}$ [11-15]. For example, Hayakawa et al. reported on the PL properties of $10 \mathrm{Al}_{2} \mathrm{O}_{3}-90 \mathrm{SiO}_{2}$ glasses annealed at $500{ }^{\circ} \mathrm{C}$, and found two emission peaks at 420 and $520 \mathrm{~nm}$, which are assigned to the point defects of oxygen deficiencies and the radical carbonyl defect $(\equiv \mathrm{Si}(\mathrm{Al})-\mathrm{O}-\mathrm{C} \cdot=\mathrm{O})$ formed on the pore surface [16]. Mir et al. incorporated $30 \mathrm{~nm}, \mathrm{Al}_{2} \mathrm{O}_{3}$ nanocrystals into silica aerogels, followed by calcination at $1150{ }^{\circ} \mathrm{C}$ in air for $2 \mathrm{~h}$. The resulting $1 \mathrm{Al}_{2} \mathrm{O}_{3}-3 \mathrm{SiO}_{2}$ composites exhibited strong, visible PL bands ranging from 400 to $600 \mathrm{~nm}$ centered at $\approx 500 \mathrm{~nm}$, which were assigned to $\mathrm{OH}$-related radiative emission centers formed in the samples [11]. Additionally, Yoldas also showed that the $\mathrm{A}_{2}{ }_{2} \mathrm{O}_{3}-\mathrm{SiO}_{2}$ composites respond to $\mathrm{UV}$ light by emission of strong, visible luminescence $(400-700 \mathrm{~nm})$, which is due to the $\left(\equiv \mathrm{Si}-\mathrm{O}{ }^{\circ} \mathrm{O}-\mathrm{Si} \equiv\right.$ ) radiative centers [17]. Chen et al. reported a peapod-like heterostructure composed of $\mathrm{SiO}_{x}$ particles orderly embedded in the highly crystalline $\alpha-\mathrm{Al}_{2} \mathrm{O}_{3}$ nanoribbons. They observed a strong and stable blue emission centered at $467 \mathrm{~nm}$ under excitation at $320 \mathrm{~nm}$, which was attributed to the neutral oxygen vacancies $(\equiv \mathrm{Si}-\mathrm{Si} \equiv)$ in the $\mathrm{SiO}_{x}-\mathrm{Al}_{2} \mathrm{O}_{3}$ heterostructure [18]. More recently, Korsunska et al. have investigated the PL behaviors of $\mathrm{Si}$-rich $\mathrm{Al}_{2} \mathrm{O}_{3}$ films annealed at $1150{ }^{\circ} \mathrm{C}$ and observed intense emission in the visible spectral range from 575 to $600 \mathrm{~nm}$, which is ascribed to defects in the matrix located near the nanocrystal/matrix interface $[13-15,19]$. From the above referenced work, it can be seen that the mechanism of this defect-dominant PL still remains ambiguous, and it is also a challenge to obtain the desired white luminescent material by control the different defects. Moreover, to date, few studies have reported on $\mathrm{Al}_{2} \mathrm{O}_{3}-\mathrm{SiO}_{2}$ nanocomposites. Thus, it is important and instructive to further explore the preparation and $\mathrm{PL}$ properties of these environmentally friendly, $\mathrm{Al}_{2} \mathrm{O}_{3}-\mathrm{SiO}_{2}$ nanomaterials.

In this work, $\mathrm{Al}_{2} \mathrm{O}_{3}-\mathrm{SiO}_{2}$ composite nanofibers with different $\mathrm{Al} /(\mathrm{Al}-\mathrm{Si})$ ratios were prepared by electrospinning in combination with calcination in air. Strong light emission was observed from the $\mathrm{Al}_{2} \mathrm{O}_{3}-\mathrm{SiO}_{2}$ hetero-nanofibers with tunable emission from bluish-white to yellow-white. The possible origins of each PL band in this composite nanofiber were also discussed.

\section{Results and Discussion Crystalline structures}

Figure 1 shows the XRD patterns of the samples with different $\mathrm{Al} /(\mathrm{Al}-\mathrm{Si})$ ratios annealed at $1200{ }^{\circ} \mathrm{C}$ in air. The diffraction peaks from pure $\mathrm{SiO}_{2}$ are located at $21.9^{\circ}, 28.5^{\circ}$, and $36.2^{\circ}$, which can be assigned to the $\langle 101>,<111>$, and $<200>$ crystalline plane of cristobalite (ICDD No. 39-1425), respectively [20,21]. The diffraction peaks of pure $\mathrm{Al}_{2} \mathrm{O}_{3}$ are located at $25.4^{\circ}, 34.92^{\circ}, 43.16^{\circ}, 52.36^{\circ}$, and $57.30^{\circ}$, which can be assigned to the $\langle 012\rangle,\langle 104\rangle,\langle 110\rangle,\langle 113\rangle,\langle 024\rangle$, and $<110>$ crystalline plane of $\alpha-\mathrm{Al}_{2} \mathrm{O}_{3}$ (ICDD No. 46-1212), respectively [22]. Once the $\mathrm{Al}_{2} \mathrm{O}_{3}$ components are mixed with $\mathrm{SiO}_{2}$, the mullite formation reaction in diphasic gels takes place between amorphous silica and transition alumina during calcination. It can be seen from the typical mullite XRD line from $\mathrm{Si}_{6} \mathrm{Al}_{4}$ samples that the diffraction peaks located at $16.51^{\circ}$, $26.25^{\circ}, 31.05^{\circ}, 33.23^{\circ}, 35.27^{\circ}, 37.05^{\circ}, 39.25^{\circ}, 40.86^{\circ}, 42.65^{\circ}$, $49.55^{\circ}, 54.09^{\circ}$, and $57.58^{\circ}$ can be assigned to the $<100>$, $<210>,<001>,<220\rangle,<111>,<130\rangle,<201>,<121>,<230\rangle$, $<311>,<321>$, and $<041>$ crystalline planes of mullite (ICDD No. 15-0776), respectively [23,24]. It is also noted that the diffraction peaks from mullite located at $26.25^{\circ}$ are clearly split into two peaks, $<120>$ and $<210>$, which is due to the fast heating process during the calcination of $\mathrm{Al}_{2} \mathrm{O}_{3}-\mathrm{SiO}_{2}$ gels [25].

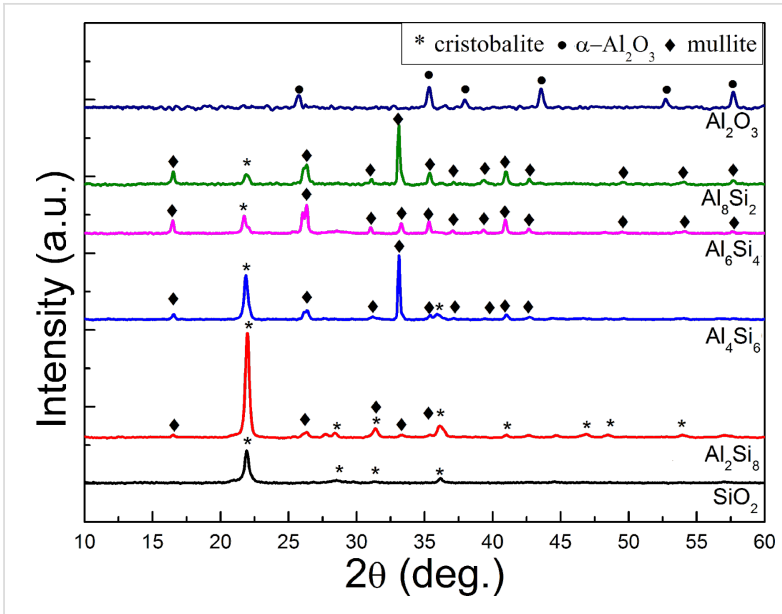

Figure 1: XRD patterns of the obtained composite nanofibers with different $\mathrm{Al} /(\mathrm{Al}-\mathrm{Si})$ ratios.

Furthermore, a diffraction peak is located at approximately $22^{\circ}$, corresponding to the $<101>$ of cristobalite, which indicates that crystalline silica phases are present in the diphasic gels during heating, while $\alpha-\mathrm{Al}_{2} \mathrm{O}_{3}$ phases can barely be detected. Wei et al. found that $\mathrm{Al}_{2} \mathrm{O}_{3}$ or cristobalite residue is formed in $\mathrm{Al}_{2} \mathrm{O}_{3}$ rich or $\mathrm{SO}_{2}$-rich, mullite specimen if the $\mathrm{A}_{2} \mathrm{O}_{3}$ content of the sample is not maintained between 60 and $66 \mathrm{~mol} \%$ [26]. In our case, the mole percent of $\mathrm{Al}_{2} \mathrm{O}_{3}$ in the diphasic gels ranges from $11 \mathrm{~mol} \%$ to $66 \mathrm{~mol} \%$, that is, most of our diphasic gels are silica-rich, except $\mathrm{Al}_{8} \mathrm{Si}_{2}$. The cristobalite residues in the Al-rich $\mathrm{Al}_{8} \mathrm{Si}_{2}$ samples might be caused by $\mathrm{Si}$ contamination from the silicon substrates used during high-temperature calcination. 


\section{Morphology and microstructure}

Figure 2a illustrates the morphology of the pure $\mathrm{Al}_{2} \mathrm{O}_{3}$ nanofibers. The diameter of the rather brittle fibers is about 100-200 nm, exhibiting a smooth surface. When $20 \mathrm{~mol} \%$ $\mathrm{SiO}_{2}$ is incorporated into the $\mathrm{Al}_{2} \mathrm{O}_{3}$ matrix, the fibers become ductile with length up to the centimeter scale and a diameter similar to the pure $\mathrm{Al}_{2} \mathrm{O}_{3}$ material. Moreover, from the enlarged SEM image shown in the inset of Figure $2 b$, some black spots were formed on the surface of fibers. This may be due to the precipitation of mullite nanocrystals from the inside to the surface of the $\mathrm{Al}_{2} \mathrm{O}_{3}$ during the calcination [18]. When the concentration of $\mathrm{SiO}_{2}$ is further increase to $40 \mathrm{~mol} \%$ (Figure 2c), the composite fibers show an obvious change, exhibiting a fused, interconnect network with a diameter of $\approx 500 \mathrm{~nm}$. This may be caused by the formation of mullite components in the samples. The continued increase in the concentration of $\mathrm{SiO}_{2}$ (to 60 and $80 \mathrm{~mol} \%$, as shown in Figure $2 \mathrm{~d}$ and Figure $2 \mathrm{e}$, respectively) results in the coarsening of the surface of the fiber, further implying the precipitation of mullite nanocrystals from the inside to the surface of the fibers during the calcination. Comparably, the pure $\mathrm{SiO}_{2}$ nanofiber has a diameter of $\approx 100 \mathrm{~nm}$ with smooth surface (Figure $2 \mathrm{f}$ ).
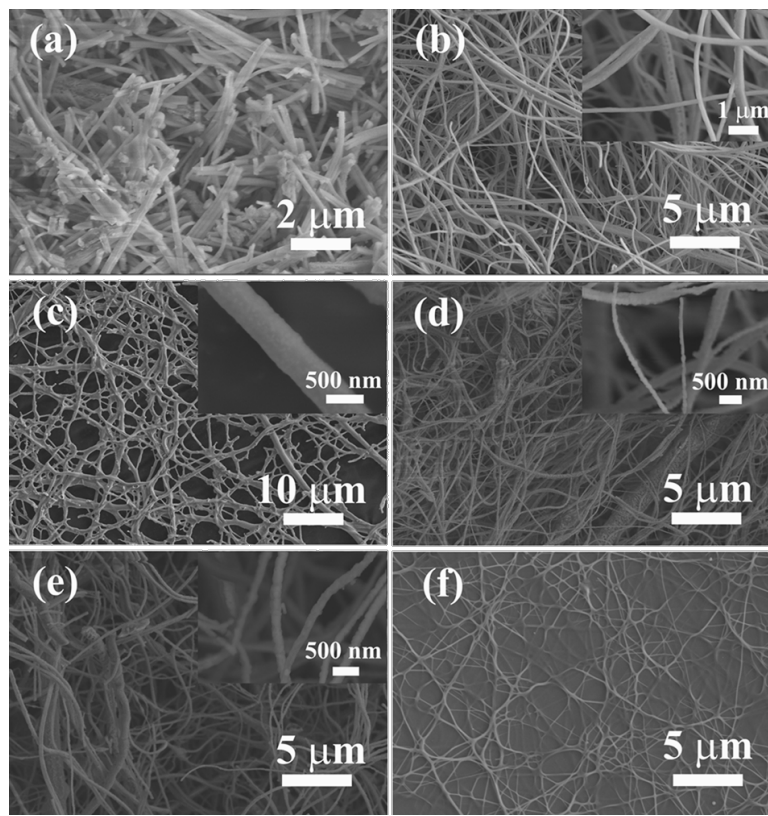

Figure 2: SEM images of the obtained composite nanofibers with different Al/(Al-Si) ratios: (a) $\mathrm{Al}_{2} \mathrm{O}_{3}$, (b) $\mathrm{Al}_{8} \mathrm{Si}_{2}$, (c) $\mathrm{Al}_{6} \mathrm{Si}_{4}$, (d) $\mathrm{Al}_{4} \mathrm{Si}_{6}$, (e) $\mathrm{Al}_{2} \mathrm{Si}_{8}$, and (f) $\mathrm{SiO}_{2}$. The insets are their corresponding enlarged SEM images.

Further studies on the microstructure and morphology of the calcined composite nanofibers were conducted by TEM. Figure $3 \mathrm{a}$ shows the morphology of the $\mathrm{Al}_{4} \mathrm{Si}_{6}$ fibers. It can be seen that the fibers have diameters of about 100-200 nm with a coarse surface, which is consistent with the above SEM results. Additionally, many nanocrystals can be observed in the enlarged TEM image shown in Figure $3 b$ with dimensions from several $\mathrm{nm}$ to several tens of $\mathrm{nm}$. The HRTEM image in Figure $3 \mathrm{c}$ illustrates that the lattice fringes are well-defined, suggesting that the composite nanowires have a high degree of crystallinity. The interplanar spacing of $0.5495 \mathrm{~nm}$ measured from the legible lattice fringes along the axis of the nanowire is quite similar to that of the $<110>$ planes of the mullite crystals $[27,28]$. In addition, some nanocrystals of cristobalite with dimensions of several tens of nm can also found on the surface of the fibers, as shown in Figure 3d. Selected area electron diffraction (SAED) patterns are collected from the thin edge of one fiber, as shown in the inset of Figure $3 \mathrm{c}$. The patterns not only verify the high degree of crystallinity of the composite nanofibers, but also indicate the disordered stacking of the formed mullite nanocrystals.

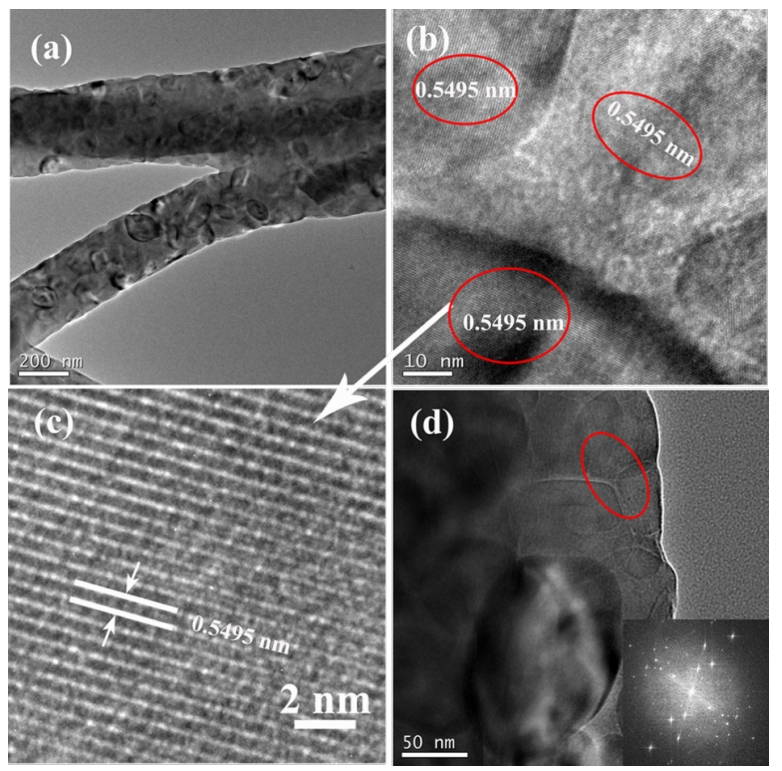

Figure 3: (a) Low magnification TEM image of $\mathrm{Al}_{4} \mathrm{Si}_{6}$ nanofibers; (b) locally enlarged TEM image; (c) HRTEM image of one area shown in (b); and (d) enlarged TEM image of the fiber surface, the inset is the SAED pattern collected from the fiber's edge.

\section{Chemical bonds}

Previous results indicate the $\mathrm{PL}$ from $\mathrm{Al}_{2} \mathrm{O}_{3}-\mathrm{SiO}_{2}$ composites is mainly due to various types of defects formed during calcination in air. Thus, to investigate the chemical bonds in the samples, FTIR measurements were also conducted. Selected IR spectra of the samples with different $\mathrm{Al} /(\mathrm{Al}-\mathrm{Si})$ ratios are shown in Figure 4, and the corresponding assignments are listed in Table 1. The IR spectra of our samples are similar to those reported for natural and synthetic silica/alumina composites [29-37]. In the wavenumber range of $400-1300 \mathrm{~cm}^{-1}$, nine, 


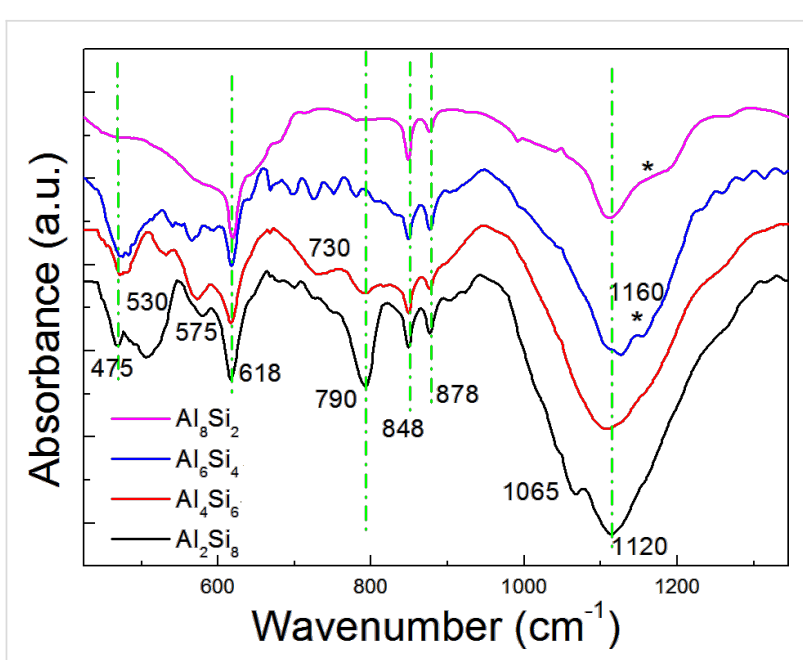

Figure 4: FTIR spectra of the composite nanofibers with different $\mathrm{Al}-\mathrm{Si}$ ratios $\left(400-1320 \mathrm{~cm}^{-1}\right)$.

\begin{tabular}{|c|c|c|}
\hline $\begin{array}{l}\text { band } \\
\text { notation }\end{array}$ & band position $\left(\mathrm{cm}^{-1}\right)$ & band assignment \\
\hline 1 & 472,1120 & $\mathrm{O}-\mathrm{Si}-\mathrm{O}$ bending $\left(\mathrm{SiO}_{4}\right)$ \\
\hline 2 & $507,530,575,618$ & $\mathrm{Al}-\mathrm{O}$ stretching $\left(\mathrm{AlO}_{6}\right)$ \\
\hline 3 & $730,848,878,1160$ & $\mathrm{Al}-\mathrm{O}$ stretching $\left(\mathrm{AlO}_{4}\right)$ \\
\hline 4 & 790 & $\mathrm{Si}-\mathrm{C}-\mathrm{O}$ bands \\
\hline 5 & 1065 & $\mathrm{SiO}-\mathrm{CO}$ \\
\hline
\end{tabular}

obvious, characteristic, IR peaks from the composite samples are observed and are located at 475, 530, 573, 618, 730, 790, 848,878 , and $1120 \mathrm{~cm}^{-1}$. The IR peak at $\approx 475 \mathrm{~cm}^{-1}$ is due to the vibrations of $\mathrm{O}-\mathrm{Si}-\mathrm{O}$ bending modes $\left(\mathrm{SiO}_{4}\right)$, whose intensity increases with an increase in the Si content. Typically, the stretching modes of an $\mathrm{AlO}_{6}$ moiety are expected in the region 500-680 $\mathrm{cm}^{-1}$, whilst comparable modes for $\mathrm{AlO}_{4}$ appear in the region of $680-880 \mathrm{~cm}^{-1}[29,30]$. Thus, the characteristic, broad adsorption peaks at 530,575 , and $618 \mathrm{~cm}^{-1}$ are assigned to Al-O stretching modes $\left(\mathrm{AlO}_{6}\right)$, and the peaks at 730,848 , and $878 \mathrm{~cm}^{-1}$ are due to the vibrations of Al-O stretching modes $\left(\mathrm{AlO}_{4}\right)[31,32]$. It can be seen that the IR peak at $790 \mathrm{~cm}^{-1}$ increases with increasing the Si content, indicating that this peak is related to the $\mathrm{Si}$ components. Referring to previous literature $[33,34]$, this IR peak at $790 \mathrm{~cm}^{-1}$ likely corresponds to the vibration of $\mathrm{Si}-\mathrm{C}-\mathrm{O}$ bonds formed due to the residual carbon elements from PVP or ethanol.

In the range of $950-1330 \mathrm{~cm}^{-1}$, the main peak intensity increases with increasing Si content, and this peak at $\approx 1120 \mathrm{~cm}^{-1}$ should be assigned to the vibrations of $\mathrm{Si}-\mathrm{O}-\mathrm{Si}$ stretching modes $\left(\mathrm{SiO}_{4}\right)$. Moreover, it is seen that the $\mathrm{Si}-\mathrm{O}-\mathrm{Si}$ stretching vibration broadens with increasing $\mathrm{Al}$ content, which is due to the formation of Al-O-Si bonds [35]. The absorption peak from the samples with high $\mathrm{Al}$ content can be split into two peaks at $\approx 1120 \mathrm{~cm}^{-1}$ and $1160 \mathrm{~cm}^{-1}$, indicating a high content of mullite [29], which is consistent with our XRD results. The new split IR peak at $1160 \mathrm{~cm}^{-1}$ is due to $\mathrm{Al}-\mathrm{O}$ stretching modes $\left(\mathrm{AlO}_{4}\right)$ [32]. In addition, from the FTIR spectrum of $\mathrm{Si}_{8} \mathrm{Al}_{2}$ samples, the sharp, shallow absorption peak, appearing at $1065 \mathrm{~cm}^{-1}$, corresponds to asymmetric stretching of $\mathrm{Si}-\mathrm{O}-\mathrm{Si}$ or $\mathrm{Si}-\mathrm{O}-$ defects [29].

\section{Photoluminescence properties}

We systematically studied the PL properties of the $\mathrm{Al}_{2} \mathrm{O}_{3}-\mathrm{SiO}_{2}$ composite nanofibers using a $325 \mathrm{~nm} \mathrm{He}-\mathrm{Cd}$ laser. Figure 5a compares the PL spectra of the pure $\mathrm{Al}_{2} \mathrm{O}_{3}, \mathrm{SiO}_{2}$, and $\mathrm{Al}_{4} \mathrm{Si}_{6}$ samples. It is noted here that the fluorescence spectrum of the $\mathrm{Al}_{4} \mathrm{Si}_{6}$ sample, which had the highest emission, can be separated into four components. One peak at $420 \mathrm{~nm}$ is due to oxygen-related defects ( $\mathrm{O}$ defects) resulting from calcination of silica, alumina, or their composites [36], and another is a broad emission peak around $520 \mathrm{~nm}$ with a shoulder peak at $550 \mathrm{~nm}$, which is the main contributor to the white emission. This $520 \mathrm{~nm}$ band can hardly be found in the pure $\mathrm{SiO}_{2}$ and $\mathrm{Al}_{2} \mathrm{O}_{3}$ samples, and this band is often assigned to radical carbonyl defects, $\equiv \mathrm{Si}(\mathrm{Al})-\mathrm{O}-\mathrm{C} \cdot=\mathrm{O}[16,37]$. In addition, anther weak emission at approximately $610 \mathrm{~nm}$ is also an important contributor to the white emission.

To further investigate the absorption process of each PL band, we measured the PL excitation (PLE) spectra of $\mathrm{Al}_{4} \mathrm{Si}_{6}$ samples at various emission positions $(420 \mathrm{~nm}, 2.95 \mathrm{eV} ; 520 \mathrm{~nm}$, $2.38 \mathrm{eV} ; 550 \mathrm{~nm}, 2.25 \mathrm{eV} ; 610 \mathrm{~nm}, 2.03 \mathrm{eV})$, which are shown in Figure 5b. The PLE spectrum monitored at $420 \mathrm{~nm}$ is a broad absorbance band centered at around $346 \mathrm{~nm}$, while the PLE spectrum monitored at $520 \mathrm{~nm}$ shows a $275 \mathrm{~nm}$ absorption peak $(4.51 \mathrm{eV})$, together with a broad shoulder around 300-400 nm. According to the previous results, the $275 \mathrm{~nm}$ absorption peak might be attributed to the absorption of mullite components formed in the samples [38], and the broad band around $300-400 \mathrm{~nm}$ to the absorption by the near-interface regions between the $\mathrm{SiO}_{2}$ and mullite crystals [39]. Moreover, the $550 \mathrm{~nm}$ emission has a similar PLE spectrum to that of the $610 \mathrm{~nm}$, indicating a similar origin of the light absorbance. From further comparison the energy of each band, it can be suggested that the $550 \mathrm{~nm}$ and $610 \mathrm{~nm}$ emissions are associated with the intersystem radiative crossing between mullites (or $\left.\mathrm{SiO}_{2}\right)$ and radical carbonyl defects $(\equiv \mathrm{Si}(\mathrm{Al})-\mathrm{O}-\mathrm{C} \cdot=\mathrm{O})$.

In order to further investigate the true origin of each band and how the Al- and Si-related components affect the PL behaviors of the composite nanofibers, we have measured the PL spec- 

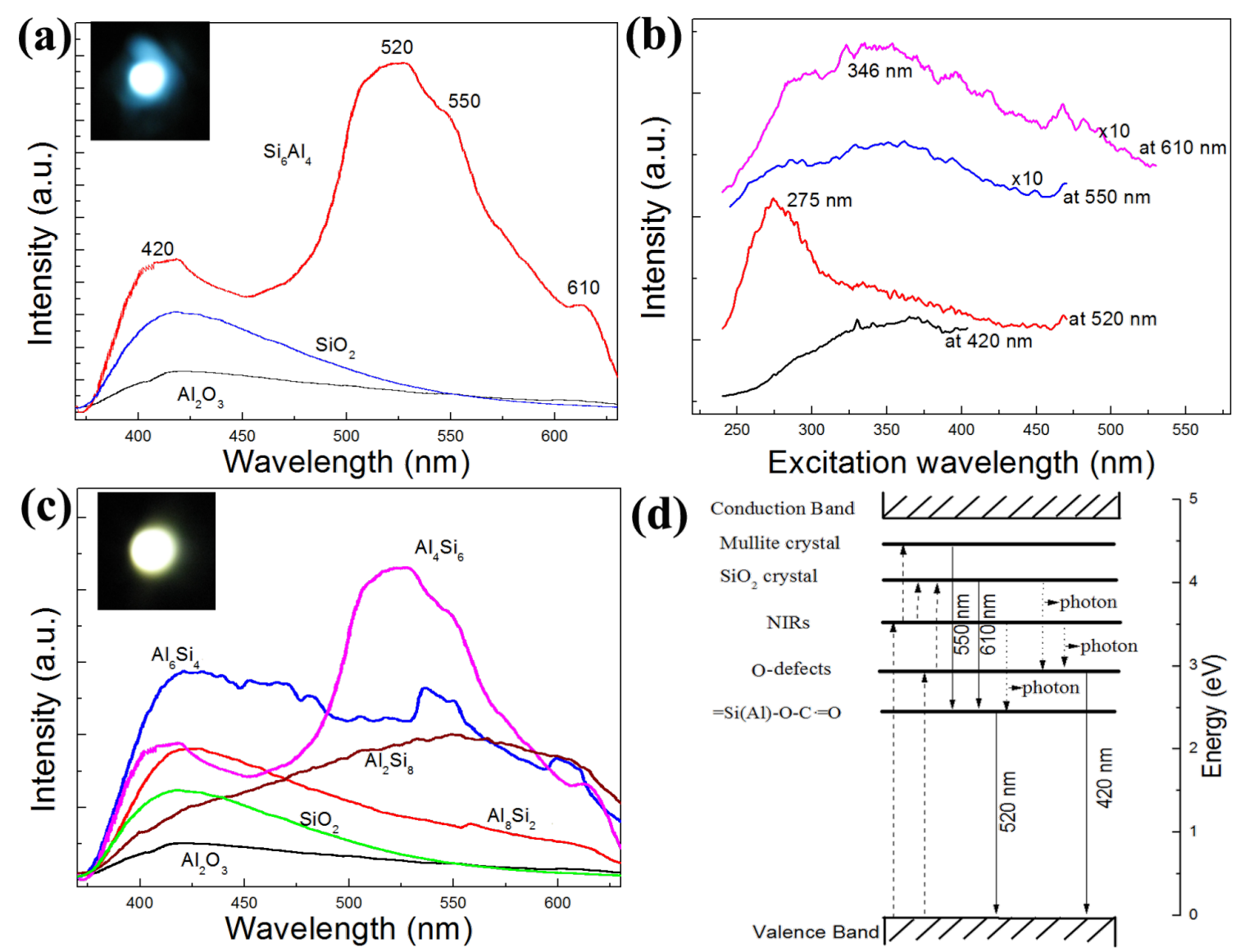

(d)

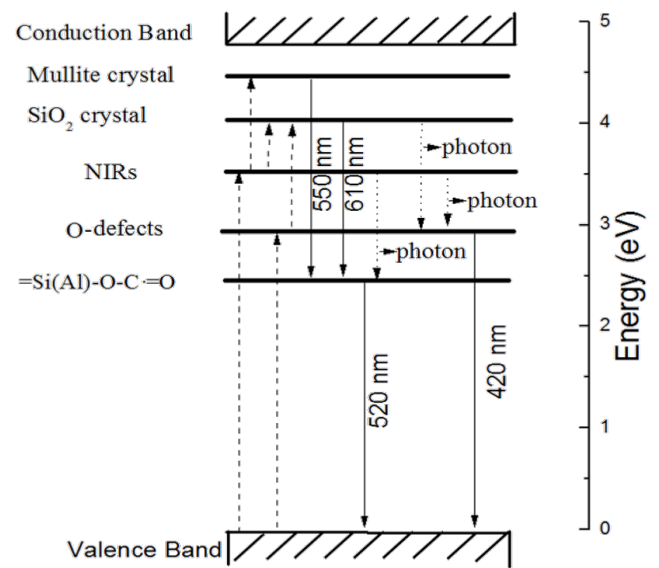

Figure 5: (a) PL comparison between the pure $\mathrm{SiO}_{2}, \mathrm{Al}_{2} \mathrm{O}_{3}$, and $\mathrm{Al}_{4} \mathrm{Si}_{6}$ nanofibers; (b) PLE spectra of $\mathrm{Al}_{4} \mathrm{Si}_{6}$ samples monitored at $420 \mathrm{~nm}$, $520 \mathrm{~nm}$, $550 \mathrm{~nm}$, and $610 \mathrm{~nm}$; (c) PL spectra of the obtained nanofibers with different Al/(Al-Si) ratios. The inset optical photos in (a) and (c) are the corresponding light emission spot of $\mathrm{Al}_{6} \mathrm{Si}_{4}$ and $\mathrm{Al}_{4} \mathrm{Si}_{6}$ samples, respectively. (d) Energy transfer diagram indicating the mechanism for $\mathrm{Al}_{2} \mathrm{O}_{3}-\mathrm{SiO}_{2}$ nanocomposite emission. The dashed lines represent light absorption, the solid lines radiative transitions, and the dotted lines nonradiative transitions.

trum of the samples with different Al-Si ratios, as shown in Figure 5c. As for the PL behavior of $\mathrm{Al}_{2} \mathrm{Si}_{8}$ nanofibers, it exhibits a dark-yellow emission with a broad band centered at about $550 \mathrm{~nm}$. It can be seen that the intensities of the 550 and $610 \mathrm{~nm}$ emissions are greatly enhanced while the $420 \mathrm{~nm}$ emission intensity is reduced as compared to that of pure $\mathrm{SiO}_{2}$. And the 550 and $610 \mathrm{~nm}$ emissions can be further enhanced with further addition of Al up to $40 \mathrm{~mol} \%$.

When the $\mathrm{Al}$ content increases to $60 \mathrm{~mol} \%$, the $\mathrm{Al}_{6} \mathrm{Si}_{4}$ nanofibers show a strong yellow-white emission, as demonstrated in the inset in Figure $5 \mathrm{c}$. This result indicates that the $520 \mathrm{~nm}$ emission deceases with more Al content and less Si content, again suggesting that the $520 \mathrm{~nm}$ emission is associated with $\mathrm{Si}-\mathrm{Al}$ defects (i.e., as the previous assignment of $\equiv \mathrm{Si}(\mathrm{Al})-\mathrm{O}-\mathrm{C} \cdot=\mathrm{O})$. From the XRD results, it can be observed that the content of crystalline $\mathrm{SiO}_{2}$ decreases with the further increase of $\mathrm{Al}$. At an $\mathrm{Al}$ content of $60 \mathrm{~mol} \%$, the samples exhibit a very high level of crystallized mullite. At the same time, less $\equiv \mathrm{Si}(\mathrm{Al})-\mathrm{O}-\mathrm{C} \cdot=\mathrm{O}$ defects can readily form during calcination in air.

Once excessive $\mathrm{Al}$ concentrations (80 and $100 \mathrm{~mol} \%$ ) are reached in the samples, the obtained nanofibers exhibit a darkblue emission with the main emission peak at $\approx 420 \mathrm{~nm}$. It can be seen that the 520,550 and $610 \mathrm{~nm}$ luminescence bands almost disappear. From the XRD results, it can be seen that only the highest degree of crystallization of mullite is obtained, with very little $\mathrm{SiO}_{2}$ and $\equiv \mathrm{Si}(\mathrm{Al})-\mathrm{O}-\mathrm{C} \cdot=\mathrm{O}$ remaining in the samples. On the other hand, the $3 \mathrm{~A}_{2}{ }_{2} \mathrm{O}_{3} \cdot 2 \mathrm{SiO}_{2}(3: 2)$ mullite components first increase with more Al addition; once excessive amounts of $\mathrm{Al}$ were added to the sample, the $2 \mathrm{~A}_{2} \mathrm{O}_{3} \cdot 1 \mathrm{SiO}_{2}(2: 1)$ mullite components formed. It is know from previous work $[38,40]$ that the $3: 2$ mullites possess a wide band gap in the range of $3.95-5.5 \mathrm{eV}$, which can be of benefit to the intersystem radiative crossing for $\equiv \mathrm{Si}(\mathrm{Al})-\mathrm{O}-\mathrm{C} \cdot=\mathrm{O}$. However, the $2: 1$ mullites have a wide band gap of $7.7 \pm 0.2 \mathrm{eV}$, which is too wide for our case. 
Therefore, based on the above analysis, we assign an energy transfer mechanism to describe our PL results, as shown in Figure 5d. First, most of the energy needed for the excitation of radical carbonyl defects $(\equiv \mathrm{Si}(\mathrm{Al})-\mathrm{O}-\mathrm{C} \cdot=\mathrm{O})$ is absorbed by the near-interface region between the $\mathrm{SiO}_{2}$ and the mullites (absorption centered at $346 \mathrm{~nm}$ ), and only a small proportion of the energy is by absorbed $\mathrm{O}$ defects. Next, a large part of the absorbed energy can be transferred nonradiatively to $\equiv \mathrm{Si}(\mathrm{Al})-\mathrm{O}-\mathrm{C} \cdot=\mathrm{O}(520 \mathrm{~nm})$, while some energy can be easily transferred to an even higher energy band $\left(\mathrm{SiO}_{2}\right.$ and mullite crystals), and rest to $\mathrm{O}$ defects $(420 \mathrm{~nm})$. At the same time, the energy transferred to mullite and $\mathrm{SiO}_{2}$ crystals can mainly intersystem radiatively cross to $\equiv \mathrm{Si}(\mathrm{Al})-\mathrm{O}-\mathrm{C} \cdot=\mathrm{O}$, emitting weak light at $550 \mathrm{~nm}$ and $610 \mathrm{~nm}$.

To better understand the effect of changing the $\mathrm{Al} /(\mathrm{Al}-\mathrm{Si})$ ratio on the PL properties of the composite nanofibers, we analyzed the raw statistics of the PL intensity for each colored luminescent center, as shown in Figure 6. The intensity of each luminescent center was integrated over the intensity area, fitted using a Gaussian fit. The $420 \mathrm{~nm}$-centered broad bands are regarded as blue light centers, the $520 \mathrm{~nm}$ and $550 \mathrm{~nm}$ bands are green light centers, and the $610 \mathrm{~nm}$ band as a red emission center. Obviously, a suitable dopant of $\mathrm{Si}$ or Al into the composite samples are required for light emission. It can be seen that the blue light centers, such as $\mathrm{O}$ defects $(420 \mathrm{~nm})$, first slightly decrease with the increasing $\mathrm{Al} /(\mathrm{Al}-\mathrm{Si})$ ratio, and then increase, and reach their minimum value at an $\mathrm{Al}$ content of $60 \mathrm{~mol} \%$ with further increase in Al content. This result indicates that suitable dopants of $\mathrm{Si}$ or Al are benefitial for this type of blue light emission. While both red and greeen centers first increase with increasing $\mathrm{Al}$ content (reaching their maximum value at $\mathrm{Al}$ contents of 0.6 and 0.4 ), they then decrease with

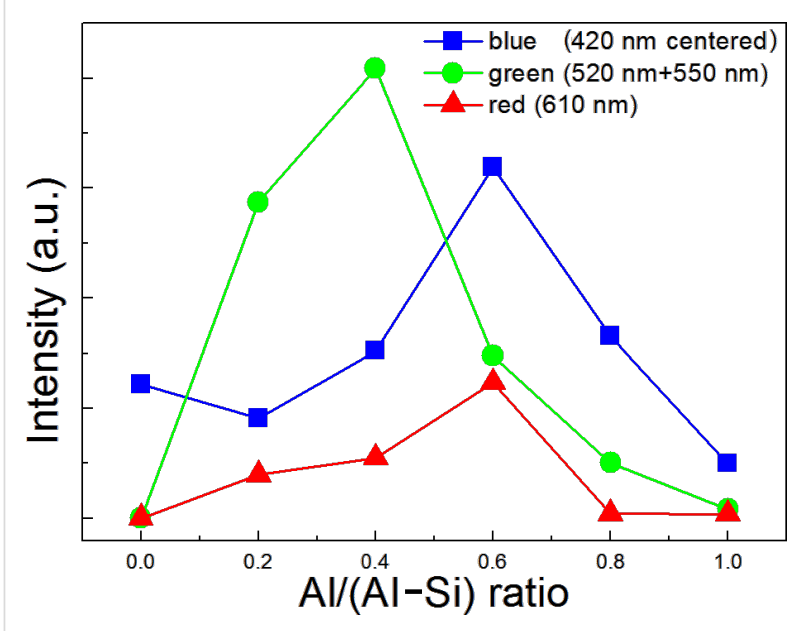

Figure 6: Integrated PL intensity of blue, green, and red luminescent centers as a function of $\mathrm{Al} /(\mathrm{Al}-\mathrm{Si})$ ratios. further Al addition. Interestingly, at Al concentrations near $60 \mathrm{~mol} \%$ and $40 \mathrm{~mol} \%$, the intensity ratio of the blue, green, and red emission components mimic white light better than the other samples's emission, and output of blue-white and yellow PL was observed as shown in the PL spots in Figure 5a and Figure 5c.

\section{Conclusion}

In summary, $\mathrm{Al}_{2} \mathrm{O}_{3}-\mathrm{SiO}_{2}$ composite nanofibers with different $\mathrm{Al} /(\mathrm{Al}-\mathrm{Si})$ ratios were prepared by electrospinning in combination with post-calcination at $1200{ }^{\circ} \mathrm{C}$ in air. The obtained composite nanofibers are comprised of mullite and cristobalite nanocrystals, and the composite fibers with a $\mathrm{Al} /(\mathrm{Al}-\mathrm{Si})$ ratio of approximately $60-80 \mathrm{~mol} \%$ exhibited a coarse surface, due to the precipitation of mullite and cristobalite nanocrystals. Furthermore, PL experiments indicate that the white light emission can be tuned by the $\mathrm{Al} /(\mathrm{Al}-\mathrm{Si})$ ratio. This is accomplished by tuning the intensity of each spectral component: violet-blue light from $\mathrm{O}$ defects, green emission from $\equiv(\mathrm{Si}) \mathrm{Al}-\mathrm{O}-\mathrm{C} \cdot=\mathrm{O}$, and red emission from the intersystem radiative crossing. This research may provide a new strategy for the preparation of environmentally friendly, white light luminescence materials.

\section{Experimental \\ Preparation of $\mathrm{Al}_{2} \mathrm{O}_{3}-\mathrm{SiO}_{2}$ composite nanofibers}

Poly(vinylpyrrolidone) (PVP, $\left.M_{\mathrm{w}} \approx 1,300,000\right)$ was purchased from Sigma-Aldrich, aluminum nitrate nanohydrate $\left(\mathrm{Al}\left(\mathrm{NO}_{3}\right)_{3} \cdot 9 \mathrm{H}_{2} \mathrm{O}\right)$ and tetraethoxysilane (TEOS) were used for the $\mathrm{Al}$ and $\mathrm{Si}$ sources, respectively, both purchased from Shantou Chemical Corp., China. All other chemicals were purchased from Tianjin Chemical Company (Tianjin, China). All chemicals were analytically pure and used as received without any further purification.

$\mathrm{Al}_{2} \mathrm{O}_{3}-\mathrm{SiO}_{2}$ hetero-nanofibers were prepared by electrospinning, the details of which can be reviewed from previously published work [41-44]. Briefly, sol-gel aqueous solutions were prepared by dissolving TEOS, $\mathrm{Al}\left(\mathrm{NO}_{3}\right)_{3} \cdot 9 \mathrm{H}_{2} \mathrm{O}$, and PVP powder (10 wt \%) in absolute ethanol. The mole ratios of $\mathrm{Al} /(\mathrm{Al}-\mathrm{Si})$ were set at $0 \mathrm{~mol} \%, 20 \mathrm{~mol} \%, 40 \mathrm{~mol} \%$, $60 \mathrm{~mol} \%, 80 \mathrm{~mol} \%$, and $100 \mathrm{~mol} \%$, and their corresponding samples are denoted as $\mathrm{SiO}_{2}, \mathrm{Al}_{2} \mathrm{Si}_{8}, \mathrm{Al}_{4} \mathrm{Si}_{6}, \mathrm{Al}_{6} \mathrm{Si}_{4}, \mathrm{Al}_{8} \mathrm{Si}_{2}$, and $\mathrm{Al}_{2} \mathrm{O}_{3}$, respectively. After strong magnetic stirring for $2 \mathrm{~h}$, the mixture was transferred into a single-nozzle electrospinning setup. The voltage and distance applied between the needle tip and the collector was set as $10 \mathrm{kV}$ and $15 \mathrm{~cm}$, respectively. The as-spun fibers were collected on silicon or quartz substrates. After electrospinning, these as-spun $\mathrm{Al}_{2} \mathrm{O}_{3}-\mathrm{SiO}_{2}$ fibers were calcined in a tube furnace in air at $1200{ }^{\circ} \mathrm{C}$ for $2 \mathrm{~h}$ to obtain pure crystalline $\mathrm{Al}_{2} \mathrm{O}_{3}-\mathrm{SiO}_{2}$ nanofibers. 


\section{Characterization}

The crystalline structure, morphology and PL properties of the final products were investigated by X-ray diffraction (XRD, Philips X'pert Pro), field-emission scanning electron microscopy (FE-SEM, Hitachi S4800), transmission electron microscopy (TEM, JEM 3000F, JOEL), Fourier transform infrared spectroscopy (FTIR, IFS66v/S, 400-4000 $\mathrm{cm}^{-1}$ ), and fluorescence spectroscopy (RF-540, Shi-Madzu) using a $15 \mathrm{~mW}, 325 \mathrm{~nm}, \mathrm{He}-\mathrm{Cd}$ laser (spot size of about $1 \mathrm{~mm}$ ) in addition to a spectroscopy with a FLS-920T spectroflorormeter (Edinburgh) with a $45 \mathrm{~W}$, Xe lamp.

\section{Acknowledgements}

This work is supported by the National Natural Science Foundation of China (No. 51202100), and partially by the Fundamental Research Funds for the Central Universities (NO.lzujbky-2013-30).

\section{References}

1. Song, H. Z.; Bao, X. M. Phys. Rev. B 1997, 55, 6988-6993. doi:10.1103/PhysRevB.55.6988

2. Sokolov, I.; Volkov, D. O. J. Mater. Chem. 2010, 20, 4247-4250. doi:10.1039/B923135H

3. Kong, D.; Zhang, C.; Xu, Z.; Li, G.; Hou, Z.; Lin, J. J. Colloid Interface Sci. 2010, 352, 278-284. doi:10.1016/j.jcis.2010.08.054

4. Liao, L.-S.; Bao, X.-M.; Li, N.-S.; Zheng, X.-Q.; Min, N.-B. J. Lumin. 1996, 68, 199-204. doi:10.1016/0022-2313(96)00023-3

5. Schmidt, M.; Heitmann, J.; Scholz, R.; Zacharias, M. J. Non-Cryst. Solids 2002, 299-302, 678-682. doi:10.1016/S0022-3093(01)01031-6

6. Liu, Z. C.; Chen, H. R.; Huang, W. M.; Gu, J. L.; Bu, W. B.; Hua, Z. L.; Shi, J. L. Microporous Mesoporous Mater. 2006, 89, 270-275. doi:10.1016/j.micromeso.2005.10.037

7. Wei, T.-Y.; Lu, S.-Y.; Chang, Y.-C. J. Chin. Inst. Chem. Eng. 2007, 38, 477-481. doi:10.1016/j.jcice.2007.05.002

8. Ishii, Y.; Matsumura, A.; Ishikawa, Y.; Kawasaki, S. Jpn. J. Appl. Phys. 2011, 50, 01AF06. doi:10.7567/JJAP.50.01AF06

9. Zhang, C.; Lin, J. Chem. Soc. Rev. 2012, 41, 7938-7961. doi:10.1039/C2CS35215J

10. Ighodaro, O. L.; Okoli, O. I. Int. J. Appl. Ceram. Technol. 2008, 5, 313-323. doi:10.1111/j.1744-7402.2008.02224.x

11. El Mir, L.; Amlouk, A.; Barthou, C. J. Phys. Chem. Solids 2006, 67, 2395-2399. doi:10.1016/j.jpcs.2006.05.059

12. Trukhin, A. N.; Sharakovski, A.; Grube, J.; Griscom, D. L. J. Non-Cryst. Solids 2010, 356, 982-986. doi:10.1016/j.jnoncrysol.2010.01.027

13. Korsunska, N.; Khomenkova, L.; Kolomys, O.; Strelchuk, V.; Kuchuk, A.; Kladko, V.; Stara, T.; Oberemok, O.; Romanyuk, B.; Marie, P.; Jedrzejewski, J.; Balberg, I. Nanoscale Res. Lett. 2013, 8, No. 273. doi:10.1186/1556-276X-8-273

14. Korsunska, N.; Stara, T.; Strelchuk, V.; Kolomys, O.; Kladko, V.; Kuchuk, A.; Khomenkova, L.; Jedrzejewski, J.; Balberg, I. Physica E 2013, 51, 115-119. doi:10.1016/j.physe.2012.12.002
15. Khomenkova, L.; Kolomys, O.; Strelchuk, V.; Kuchuk, A.; Kladko, V.; Baran, M.; Jedrzejewski, J.; Balberg, I.; Marie, P.; Gourbilleau, F.; Korsunska, N. Mater. Res. Soc. Symp. Proc. 2013, 1617, 75-80. doi:10.1557/opl.2013.1167

16. Hayakawa, T.; Hiramitsu, A.; Nogami, M. Appl. Phys. Lett. 2003, 82, 2975-2977. doi:10.1063/1.1569038

17. Yoldas, B. E. J. Mater. Res. 1990, 5, 1157-1158. doi:10.1557/JMR.1990.1157

18. Chen, D.-Y.; Shao, M.-W.; Cheng, L.; Wang, X.-H.; Ma, D. D.-D. Appl. Phys. Lett. 2009, 94, 043101. doi:10.1063/1.3070319

19. Khomenkova, L.; Kolomys, O.; Baran, M.; Kuchuk, A.; Strelchuk, V.; Venger, Y.; Kladko, V.; Jedrzejewski, J.; Balberg, I.; Korsunska, N. Microelectron. Eng. 2014, 125, 62-67. doi:10.1016/j.mee.2013.12.001

20. Elzea, J. M.; Odom, I. E.; Miles, W. J. Anal. Chim. Acta 1994, 286, 107-116. doi:10.1016/0003-2670(94)80182-7

21. Tong, Q.; Wang, J.; Li, Z.; Zhou, Y. J. Eur. Ceram. Soc. 2008, 28, 1227-1234. doi:10.1016/j.jeurceramsoc.2007.09.051

22. Yang, W.; Wang, H.; Cheng, X.; Xie, Z.; An, L. J. Am. Ceram. Soc. 2008, 91, 2732-2735. doi:10.1111/j.1551-2916.2008.02483.x

23. Sundaresan, S.; Aksay, I. A. J. Am. Ceram. Soc. 1991, 74, 2388-2392. doi:10.1111/j.1151-2916.1991.tb06773.x

24. Osendi, M. I.; Baudin, C.; de Aza, S.; Moya, J. S. Ceram. Int. 1992, 18, 365-372. doi:10.1016/0272-8842(92)90067-N

25. de Sola, E. R.; Torres, F. J.; Alarcón, J. J. Eur. Ceram. Soc. 2006, 26 , 2279-2284. doi:10.1016/j.jeurceramsoc.2005.04.015

26. Wei, W.-C.; Halloran, J. W. J. Am. Ceram. Soc. 1988, 71, 166-172. doi:10.1111/j.1151-2916.1988.tb05023.x

27. Zhang, P.; Liu, J.; Du, H.; Li, S.; Xu, R. Chem. Commun. 2010, 46, 3988-3990. doi:10.1039/B927556H

28. Huo, K.; Zhu, B.; Fu, J.; Li, X.; Chu, P. K. J. Nanosci. Nanotechnol. 2010, 10, 4792-4796. doi:10.1166/jnn.2010.1700

29. Nampi, P. P.; Moothetty, P.; Berry, F. J.; Mortimer, M.; Warrier, K. G. Dalton Trans. 2010, 39, 5101-5107. doi:10.1039/c001219j

30. Leivo, J.; Lindén, M.; Rosenholm, J. M.; Ritola, M.; Teixeira, C. V.; Levänen, E.; Mäntylä, T. A. J. Eur. Ceram. Soc. 2008, 28, 1749-1762. doi:10.1016/j.jeurceramsoc.2007.12.033

31. Voll, D.; Lengauer, C.; Beran, A.; Schneider, H. Eur. J. Mineral. 2001, 13, 591-604. doi:10.1127/0935-1221/2001/0013-0591

32. Voll, D.; Angerer, P.; Beran, A.; Schneider, H. Vib. Spectrosc. 2002, 30, 237-243. doi:10.1016/S0924-2031(02)00030-9

33. Innocenzi, P. J. Non-Cryst. Solids 2003, 316, 309-319. doi:10.1016/S0022-3093(02)01637-X

34. Simon, S.; Tămăşan, M.; Radu, T.; Simon, V. Eur. Phys. J.: Appl. Phys. 2011, 55, 30401. doi:10.1051/epjap/2011100524

35. Wu, L.; Huang, Y.; Wang, Z.; Liu, L.; Xu, H. Appl. Surf. Sci. 2010, 256, 5973-5977. doi:10.1016/j.apsusc.2010.03.104

36. Hou, Z.; Zhang, C.; Li, C.; Xu, Z.; Cheng, Z.; Li, G.; Wang, W.; Peng, C.; Lin, J. Chem. - Eur. J. 2010, 16, 14513-14519. doi:10.1002/chem.201000900

37. Skuja, L. J. Non-Cryst. Solids 1994, 179, 51-69. doi:10.1016/0022-3093(94)90684-X

38. Aryal, S.; Rulis, P.; Ching, W.-Y. J. Am. Ceram. Soc. 2012, 95, 2075-2088. doi:10.1111/j.1551-2916.2012.05172.x

39. Zhou, J.; Xu, X.; Song, X.; Chen, Z.; Zhou, M.; Chen, C.; Liu, Y.; Song, J.; Xie, E. J. Mater. Res. 2010, 25, 1041-1048. doi:10.1557/JMR.2010.0144

40. Khatim, O.; Nguyen, T. H. N.; Amamra, M.; Museur, L.; Khodan, A.; Kanaev, A. Acta Mater. 2014, 71, 108-116. doi:10.1016/j.actamat.2014.03.006 
41.Zhou, J.-Y.; Chen, Z.-Y.; Zhou, M.; Gao, X.-P.; Xie, E.-Q. Nanoscale Res. Lett. 2009, 4, 814-819. doi:10.1007/s11671-009-9320-Z

42. Wang, W.; Zhou, J.; Zhang, S.; Song, J.; Duan, H.; Zhou, M.; Gong, C.; Bao, Z.; Lu, B.; Li, X.; Lan, W.; Xie, E. J. Mater. Chem. 2010, 20, 9068-9072. doi:10.1039/C0JM02120B

43. Song, J.; Zhou, J.; Wang, W.; Liu, Y.; Li, X.; Xu, X.; An, X.; Xie, E. J. Phys. Chem. C 2010, 114, 10761-10767. doi:10.1021/jp103029z

44. Liu, Y.; Zhang, H.; An, X.; Gao, C.; Zhang, Z.; Zhou, J.; Zhou, M.; Xie, E. J. Alloys Compd. 2010, 506, 772-776. doi:10.1016/j.jallcom.2010.07.067

\section{License and Terms}

This is an Open Access article under the terms of the Creative Commons Attribution License

(http://creativecommons.org/licenses/by/2.0), which permits unrestricted use, distribution, and reproduction in any medium, provided the original work is properly cited.

The license is subject to the Beilstein Journal of

Nanotechnology terms and conditions:

(http://www.beilstein-journals.org/bjnano)

The definitive version of this article is the electronic one which can be found at: doi:10.3762/bjnano.6.29 